\title{
The Elephant in the Room: Dealing with an Unprosecuted Criminal Disclosure in a Therapeutic Setting
}

Daly-Lynn, J., Daly, C., \& Rhys, C. (2016). The Elephant in the Room: Dealing with an Unprosecuted Criminal Disclosure in a Therapeutic Setting. Journal of Forensic Psychology, 1(4), 1-8. https://doi.org/10.4172/2475319X.1000114

Link to publication record in Ulster University Research Portal

\section{Published in:}

Journal of Forensic Psychology

Publication Status:

Published (in print/issue): 30/11/2016

DOI:

10.4172/2475-319X.1000114

\section{Document Version}

Publisher's PDF, also known as Version of record

\section{General rights}

Copyright for the publications made accessible via Ulster University's Research Portal is retained by the author(s) and / or other copyright owners and it is a condition of accessing these publications that users recognise and abide by the legal requirements associated with these rights.

\section{Take down policy}

The Research Portal is Ulster University's institutional repository that provides access to Ulster's research outputs. Every effort has been made to ensure that content in the Research Portal does not infringe any person's rights, or applicable UK laws. If you discover content in the Research Portal that you believe breaches copyright or violates any law, please contact pure-support@ulster.ac.uk. 


\title{
The Elephant in the Room: Dealing with an Unprosecuted Criminal Disclosure in a Therapeutic Setting
}

\author{
Jean Daly Lynn ${ }^{1^{*}}$, Clare Daly ${ }^{2}$ and Catrin Rhys ${ }^{3}$
}

1School of Health Sciences, University of UIster, Jordanstown campus, Shore Road, Newtownabbey, Co. Antrim, BT37 OQB, Northern Ireland

2Ronan Daly Jermyn, 2 Park Place, Mahon Point, Cork, Ireland.

3 School of Communication, University of Ulster, Jordanstown campus, Shore Road, Newtownabbey, Co. Antrim, BT37 OQB, Northern Ireland.

*Corresponding Author: Jean Daly Lynn, School of Health Sciences, University of Ulster, Jordanstown campus, Shore Road, Newtownabbey, Co. Antrim, BT37 0QB, Northern Ireland, Tel: 00442890368244; E-mail: j.daly@ulster.ac.uk

Received: November 01, 2016; Accepted: November 23, 2016; Published: November 30, 2016

Copyright: (c) 2016 Lynn JD, et al. This is an open-access article distributed under the terms of the Creative Commons Attribution License, which permits unrestricted use, distribution, and reproduction in any medium, provided the original author and source are credited.

\begin{abstract}
Aims: The present study sought to explore the ethical and legal challenges faced by therapists following a client's disclosure of an unprosecuted criminal offence during therapy.

Methods: A questionnaire was developed to collect demographic information, to investigate therapists' levels of legal knowledge; and to identify reporting behavior following a client's disclosure of a past crime through eight hypothetical scenarios. Four semi-structured interviews were carried out using the hypothetical scenarios to explore the decision making process in further depth.

Results: The findings highlighted that just over half the respondents felt they were not adequately informed about their legal obligations to report disclosures. Non-reporting emerged as a significant issue in the hypothetical scenarios. Further analysis highlighted that reporters tended to have greater legal knowledge and increased training levels but had higher levels of discomfort in making the decision to report.

Discussion: The findings suggested that respondents are aware of their legal duty to report but in practice do not follow through on this duty. A significant number of social, therapeutic and personal factors impacted on the decision making process such as the crime; the impact on therapy; the client's disclosure; legal obligation; and personal characteristics of the therapist.
\end{abstract}

Keywords: Ethical dilemma; Unprosecuted criminal offence; Mandatory reporting; Disclosures

\section{Introduction}

'Moving forwards towards health and healing means that uncomfortable truths have to be faced. The therapy room is a place where this "facing into" what we have done so often begins' (Participant 20).

Confidentiality is a fundamental component to therapy as otherwise clients could not be expected to divulge intimate, sometimes embarrassing and possibly personally damaging information [1]. Factors such as shame, fear, legal implications or embarrassment can prevent a disclosure, which can obstruct one's social, intellectual, psychological, behavioral and physical functioning [2]. Confidentiality is the duty to protect a client's privacy and breaking this trust can lead to the destruction of the therapeutic relationship [3]. The therapeutic relationship is one of the key factors associated with positive therapeutic outcomes [4]. Therefore, without confidentiality and a strong therapeutic alliance, a therapist cannot provide effective treatment [5].

The legal basis for confidentiality is enshrined in the statutory provisions, such as the Data Protection Act 1998 and the Human Rights Act 1998, and in both common and contract law. There are three broad exceptions for breaching confidentiality: if it is required by law, when there is consent or if there is a risk of harm to a third party [6]. Breaching confidentiality to prevent crime and to protect the public is set out in statute and common law. However, it becomes more unclear in relation to unprosecuted criminal offences from the past. Criminal prosecution is assumed to be necessary to discourage a person offending again in the future; to deter the public from offending; to uphold justice and to achieve closure for the victim and their family. However, criminal prosecution cases tend to adopt a case by case approach and the outcome depends on the specific features of the case [7].

The Department of Health and Social Services offered guidance on the types of disclosures required in Northern Ireland, such as the 'prevention of serious harm to third parties; child protection; protecting vulnerable adults; prevention of terrorism; prevention, detection or prosecution of a serious crime; misuse of controlled drugs; investigation of serious professional misconduct...' [8]. Therefore, it is necessary for a therapist to interpret the guidelines, while considering the disclosure, to determine if a serious crime has been committed. Evidence in the UK suggests that therapists have a strong legal and ethical case for maintaining the confidentiality of a child making a disclosure of abuse to avoid problems such as the retraction of the disclosure and to provide the child with a confidential space [9]. However, Bond et al. [10] confirmed that, it would be unlikely that the professional confidentially maintained during therapy could override 
the interest of justice in relation to an unprosecuted crime. Therefore, therapist/client confidentiality is not a justification for withholding information in the eyes of the law.

Therapists need to be prepared to hear unpleasant and unusual disclosures about actions a client may deeply regret. At times, this may include crimes of varying degrees of severity that have gone unprosecuted. Psychologists and psychotherapists are obliged to practice within this complex framework of legislation. Similarly, practitioners agree to abide by an ethical framework when they become members of a professional organization. However, these ethical standards can undoubtedly collide with legal requirements especially in relation to confidentiality [5].

There is a range of legislation that limit clients' privilege to absolute confidentiality following disclosures of unprosecuted criminal offences in the UK such as The Terrorism Act 2000, Drug Trafficking Act 1994, Proceeds of Crime Act 2002, or the Money Laundering Regulations 2007. Provisions setting out a legal duty to breach confidentiality can be complex and confusing. For example, in Northern Ireland, the Criminal Law (Northern Ireland) Act 1967 (hereinafter "the 1967 Act") provides that mandatory reporting is a legal requirement. In Section 5 of the 1967 Act it states that it is a criminal offence to fail to disclose information relating to a relevant offence to the appropriate authorities without a reasonable excuse. However, Section 5 of the 1967 Act has come under criticism on the grounds of its ambiguous wording and its application in therapeutic practice [11,12]. Hence, therapists have significant legal obligations in the face of a disclosure, despite the fact practitioners do not have enough guidance to interpret the complexities within the law and apply the framework to practice.

Northern Ireland is still in a transition to peace and the impact of the Troubles resonates within society [13]. The thirty-year conflict in Northern Ireland is considered the most intense and violent conflict in Europe [14]. The Troubles was the result of social and economic inequality [15] and central to this conflict lay the constitutional status of Northern Ireland. The Catholic nationalists wanted to be part of a united Ireland and the Protestant unionists wanted to remain as part of the United Kingdom [16]. The legacy of this conflict has had a massive impact on society and tension still resonates in society today, although a peace process was established in 1998 [13]. The research highlights that many families in Northern Ireland have been impacted by the Troubles [17]. The unresolved issues of the past hamper individuals moving beyond the conflict and in doing so, threaten the political and social development of Northern Ireland [18]. The most disturbing memories from the Troubles can be because of criminal activity [19]. Similarly, potential clients, such as victims, ex-paramilitaries, members of the security forces, could divulge information relating to criminal activity during the Troubles, that has gone unprosecuted. There is limited research to investigate how the Troubles have impacted social and health care services [20]. Internationally, a number of societies live in a transition to peace after conflict [21] or within environments where organized crime, gangs and criminality along with violence, intimidation and social control are a part of daily life [22]. Therefore, it is essential to establish a way for clients to communicate the suffering and experiences of past crimes [23]. However, to enable people to speak about the unspeakable both the client and the therapist must be aware of what can and cannot be said, and that the implications of sharing sensitive information are set out from the outset.

If a therapist unnecessarily reports their clients' disclosure to the police it can have a negative impact in several ways. It can lead to damaging the established therapeutic relationship, result in a legal claim against the therapist for negligence, a risk of professional conduct complaints and limit any future interventions for the client [24]. On the other hand, the non-disclosure of information can result in a risk of prosecution for the therapist, the possibility of a client committing another serious offence putting the safety of the public at risk, as well as limiting the authorities' ability to establish a conviction [11]. Accordingly, the decision to report or not to report can have severe consequences. The existing international literature on mandatory reporting focuses primarily on a therapist's duty to warn on the grounds of public interest $[25,26]$ and on the mandatory reporting of child abuse $[27,28]$. However, it fails to address the dilemma faced by therapists when a client discloses an unprosecuted criminal offence.

Limited international research has explored the implications of therapist's ethical and legal obligations relating to the disclosure of unprosecuted criminal offences. In Australia, a research team highlighted therapists' confusion regarding their legal duty to report clients they believe to be in danger, and also suggested that therapists are more comfortable with their ethical obligations in contrast to their legal obligations [29]. Similarly, in the United States of America, Pabian et al. [24] found over seventy-six per cent of respondents were misinformed about their state laws, although respondents felt confident in the knowledge of their duty to warn obligations. Additionally, Walfish et al. [30] found therapists in the US are generally aware of their duty to warn obligations when a third party is in danger, but are not clear on the issue of reporting past violence.

Minimal empirical research in the UK has explored therapist's ethical and legal obligations relating to disclosures of unprosecuted criminal offences. One study used qualitative methods to explore therapists' understanding of legal and ethical dilemmas and found a lack of clarity relating to their legal obligations in the UK [31]. Numerous other issues emerged such as the negative implications of mandatory information sharing with other agencies, the poor integration of legal obligations into practice and the complex multidimensional nature of an ethical and legal dilemma.

The literature highlights the discrepancy between therapists' ethical and legal obligations. Confidentiality has fundamental importance in the therapeutic relationship, however, the limitations of confidentiality are often unclear in a therapeutic setting and pose a significant risk to this relationship. The focus of the current study is to investigate therapists' knowledge, reporting behavior and decision making in response to the disclosure of an unprosecuted criminal offence in a therapeutic setting in the Northern Irish context.

\section{Methods}

A mixed methods design was used to explore therapist response to the challenges of an unprosecuted criminal offence disclosed in a therapeutic setting and to understand therapists' knowledge of ethical and legal issues in greater depth. A questionnaire was developed to establish a demographic overview of the participant and their awareness of legal obligations. The eight complex scenarios were developed to explore therapist's response to challenges presented from clients disclosing information of unprosecuted criminal offences in a therapeutic setting. The purpose of the complex scenarios was to examine therapists reporting behavior and identify how comfortable they felt presented with each situation. The complex scenarios were developed based on the literature surrounding the Troubles in Northern Ireland. The literature consulted included victim accounts from previous research $[19,32]$. The focus remained purely on Troubles 
related unprosecuted criminal offences that are associated with the history and experiences of the population in Northern Ireland. The scenarios include crimes on the spectrum from very serious to less serious such as murder, community style punishment beatings, drug dealing, and rioting.

The clients vary in each scenario to include different types of perpetrators and/or victims. For each complex scenario, the survey asks firstly how the therapist would proceed (1: report to the police immediately, 2: maintain the client's confidentiality, 3: hold this information until a decision is reached between client and therapist, 4: other (please comment)) and secondly, how they rate their comfort levels following the client's disclosure (1: Extremely uncomfortable to 4: Extremely comfortable). A third open question provides space for the therapist to note any other issues that the scenario raised for them.

Semi-structured interviews were subsequently carried out to explore participants' knowledge of their ethical and legal obligations in each of the hypothetical situations and to investigate the factors that influenced their reporting decision. Ethical approval was obtained from the School of Communication in Ulster University. Ethical considerations were crucial to keep both the participants and the researchers safe from disclosures. Therefore, informed consent was obtained and each interview centered on the hypothetical scenarios.

\section{Participants}

Psychologists, counsellors and psychotherapists were recruited by carrying out online searches of public registers. Two hundred and nine questionnaires were distributed and forty-two questionnaires were returned giving a response rate of $20.1 \%$. Six participants contacted the researcher to take part in the interview phase and four interviews were held ( 2 female: 2 male). All four interview participants worked in private practice as well the National Health Service (NHS), voluntary organizations, and were practicing supervisors. The survey participants varied from between one and over twenty years of experience, with most respondents having between 5 and 9 years' experience. Primarily, respondents reported using an integrative theoretical approach (67.5\%) and worked in an urban setting (60\%). The greatest proportion of respondents held an MSc qualification (37.5\%) and additionally, a total of $32.5 \%$ of respondents held a diploma in supervision.

\section{Results}

'A society which does not support those who try to maintain the law faces breakdown' (Participant 40).

\section{Knowledge of legal obligations}

The participants' responses to the questionnaire relating to knowledge of their legal obligations are outlined in Table 1. A total of $60 \%$ of respondents with a master's degree reported that they did not feel adequately informed about their legal obligations. Eighty-one per cent of the respondents that did feel adequately informed about their legal obligations had undertaken training. A total of $73.7 \%$ of respondents that felt they were not adequately informed about their legal obligations, reported that they believed there was a legal duty to report a client's disclosure of an unprosecuted criminal offence. On the other hand, $23.8 \%$ of respondents that felt informed about their legal obligations, reported that there was no legal duty to report a client's disclosure of an unprosecuted criminal offence. Furthermore, $42.9 \%$ of respondents that felt informed about their legal obligations did not think that the Criminal Law (1967) Act influenced therapeutic practice.

\begin{tabular}{|l|l|l|}
\hline \multicolumn{1}{|c|}{ Question } & \multicolumn{1}{|c|}{ Yes } & No \\
\hline Has a client ever disclosed information regarding an unprosecuted criminal offence during therapy? & $37.50 \%$ & $62.50 \%$ \\
\hline Is there a legal duty to report an unprosecuted criminal offence disclosed during therapy? & $75 \%$ & $25 \%$ \\
\hline Do you feel adequately informed about your legal obligations as a therapist? & $52.50 \%$ & $47.50 \%$ \\
\hline Have you ever received training about your legal obligations as a therapist? & $56.40 \%$ & $43.60 \%$ \\
\hline Does the Criminal Law (Northern Ireland) Act (1967) influence the way you work as a therapist? & $43.60 \%$ & $56.40 \%$ \\
\hline
\end{tabular}

Table 1: Therapists knowledge of legal obligations.

\section{Reporting behavior}

Each vignette presented different circumstances with clients ranging from victims to perpetrators (Table 2). Of the eight scenarios, seven presented serious crimes that should have been reported by law according to the definition of serious crimes set out by the Department of Health and Social Services in Northern Ireland [8]. Scenarios three and eight were largely unreported as the client was the victim or the crime was viewed as less severe in nature by the participants. Across the scenarios, $0 \%$ to $21.4 \%$ of the respondents opted for immediate reporting. Furthermore, combined with those who would immediately report, $0 \%$ to $55.3 \%$ indicated that the therapist and client would begin a process that would lead ultimately to one of them reporting the disclosure to the authorities. The findings varied from $40.6 \%$ to $100 \%$ in relation to withholding the information between the therapist and the client in the therapeutic relationship and this was the most typical response for the eight scenarios.

The four interview participants had different approaches in their decision-making process but which often resulted in the same outcome. Participant A placed the emphasis on the contract and the boundaries of therapy during the decision-making process. Participant $B$ had very clear knowledge of the legal obligations and measured these obligations against each scenario. In contrast to this, Participant $\mathrm{C}$ saw the therapist's role as supportive and works with the client to achieve their disclosure rather than disclose against the client's wishes. Participant D implemented a three-step process to reach a decision: to protect the therapeutic relationship; to remind the client about the contract; and to discuss the most appropriate way to manage the information that had been disclosed. 
Citation: Lynn JD, Daly C, Rhys C (2016) The Elephant in the Room: Dealing with an Unprosecuted Criminal Disclosure in a Therapeutic Setting. J Foren Psy 1: 114. doi:10.4172/2475-319X.1000114

Page 4 of 8

\begin{tabular}{|c|c|c|c|c|c|}
\hline Scenario & Crime & $\begin{array}{l}\text { Reported } \\
\text { immediately }\end{array}$ & $\begin{array}{l}\text { Ultimately } \\
\text { Reported }\end{array}$ & Comfort Level & $\begin{array}{l}\text { Issues Impacting } \\
\text { Decision }\end{array}$ \\
\hline 1 & $\begin{array}{l}\text { The client discloses witnessing a paramilitary shooting. } \\
\text { She recognizes the murderer from her community but she } \\
\text { is afraid to go to the police for fear of paramilitary reprisal. } \\
\text { The client discloses the perpetrator's name and that she } \\
\text { fears for the safety of another person in the community. }\end{array}$ & $15.8 \%$ & $55.3 \%$ & $47.3 \%$ & $\begin{array}{l}\text { Safety/fear; moral } \\
\text { obligation }\end{array}$ \\
\hline 2 & $\begin{array}{l}\text { The client's father was murdered and the family } \\
\text { subsequently received death threats. To protect his family } \\
\text { the client joined a paramilitary group and got caught up in } \\
\text { violence. The client confessed to throwing a petrol bomb } \\
\text { at a house that consequently killed a woman and her two } \\
\text { young children. }\end{array}$ & $18.4 \%$ & $50 \%$ & $50 \%$ & $\begin{array}{l}\text { Safety/fear; moral } \\
\text { obligation }\end{array}$ \\
\hline 3 & $\begin{array}{l}\text { The client discloses having been kidnapped on his way } \\
\text { home from work and endured physical and mental torture } \\
\text { for three days. It was a case of mistaken identity and the } \\
\text { client was dumped at the side of the road at the end of the } \\
\text { ordeal. The client is in significant psychological pain and } \\
\text { has a permanent physical disability. The client sees his } \\
\text { abductors in his community on a regular basis. }\end{array}$ & $2.9 \%$ & $2.9 \%$ & $57.1 \%$ & $\begin{array}{l}\text { Lack of evidence; } \\
\text { client's choice }\end{array}$ \\
\hline 4 & $\begin{array}{l}\text { The client discloses involvement in the Belfast rioting } \\
\text { during the marching season in } 2010 \text {. He confessed to } \\
\text { throwing petrol bombs, bricks and stones at the police and } \\
\text { their vehicles. One of the bricks hit a member of the police } \\
\text { and seriously injured her. The client states that he has } \\
\text { never been involved in any criminal activity before. }\end{array}$ & $17.1 \%$ & $45.7 \%$ & $48.5 \%$ & $\begin{array}{l}\text { Definition of a serious } \\
\text { crime; potential to } \\
\text { continue therapy }\end{array}$ \\
\hline 5 & $\begin{array}{l}\text { The client discloses his active membership as a } \\
\text { paramilitary during the troubles and that he was } \\
\text { responsible for a car bomb attack in a village killing five } \\
\text { people. However, the client was subsequently identified } \\
\text { as an informer by his own paramilitary group and was } \\
\text { shot in both knees. He is struggling to come to terms with } \\
\text { his disability and is still receiving death threats and } \\
\text { intimidation. }\end{array}$ & $19.4 \%$ & $41.6 \%$ & $51.5 \%$ & $\begin{array}{l}\text { Safety/fear; potential to } \\
\text { continue therapy }\end{array}$ \\
\hline 6 & $\begin{array}{l}\text { The client who is a member of the Police Service Northern } \\
\text { Ireland discloses having given weapons to loyalist } \\
\text { paramilitaries during the Troubles and confessed to being } \\
\text { a member of the UVF. The client regrets covering up and } \\
\text { not investigating murders on three occasions so that it } \\
\text { reduced the possibility of someone being prosecuted for } \\
\text { the murders. The client is still in a prominent position in } \\
\text { the police, is an active member of the church in his } \\
\text { community and is no longer a member of the UVF. }\end{array}$ & $18.2 \%$ & $45.5 \%$ & $48.4 \%$ & $\begin{array}{l}\text { Value of reporting; } \\
\text { moral obligation }\end{array}$ \\
\hline 7 & $\begin{array}{l}\text { The client discloses being a leading member of a } \\
\text { paramilitary organization during therapy, although he said } \\
\text { he has had limited involvement in the organization in the } \\
\text { previous two years. He confesses orchestrating } \\
\text { assassinations and bombing campaigns during the } \\
\text { Troubles. Although he feels his politically motivated } \\
\text { actions are justified, he feels guilty and remorseful. During } \\
\text { therapy the client goes into detail about a particular } \\
\text { incident when he shot a policeman. }\end{array}$ & $21.9 \%$ & $53.2 \%$ & $54.8 \%$ & $\begin{array}{l}\text { Safety/fear; } \\
\text { obligation }\end{array}$ \\
\hline 8 & $\begin{array}{l}\text { The client discloses getting involved in drug taking and } \\
\text { drug dealing in his adolescence. He discloses that at } 17 \\
\text { years of age three members of the local paramilitary } \\
\text { group beat him severely as a punishment for getting } \\
\text { involved in this type of anti-social behavior. The client } \\
\text { experiences severe flashbacks and he uses alcohol and } \\
\text { drugs to cope with the traumatic memories. }\end{array}$ & $0 \%$ & $0 \%$ & $77.4 \%$ & $\begin{array}{l}\text { Definition of a serious } \\
\text { crime; value of reporting }\end{array}$ \\
\hline
\end{tabular}

Table 2: Reporting behavior.

\section{The decision-making process}

In considering the decision-making process that participants engaged in, three main themes emerged from the triangulation of the data from the questionnaires and the interviews: social factors, therapeutic factors and personal factors. The social factors impacting on the decision to report an unprosecuted crime are outlined in Table 
Page 5 of 8

3. Strikingly, the participants suggested that the culture of Northern Ireland and the impact of the Troubles filter into the counselling setting. It seems that therapists can bring their own experiences of the Troubles into therapy and this can add an additional dimension to the decision-making process. In particular, the culture of not reporting and community imposed silence can be reflected in the counselling setting. It was highlighted that the fear of the repercussions from reporting a client's disclosure significantly affects how the therapist would proceed. This fear would impact on the decision to report because of the effect it would have on both the professional and personal life of the therapist.

\begin{tabular}{|l|l|}
\hline \multicolumn{1}{|c|}{ Sub-Theme } & \\
\hline The Culture & '...not telling tales, not shopping people, there is still a lot of that here you know, it has never left...' \\
\hline $\begin{array}{l}\text { The Fear Associated with } \\
\text { Disclosure }\end{array}$ & 'At a personal level if you take all the fear away the answer to most of these would be absolutely...' \\
\hline The Severity of the Crime & 'I do not feel I need to go rushing out to ring the police because my client is throwing stones at the police' \\
\hline Risk & $\begin{array}{l}\text { 'The issue for me is only if I believe that serious harm is going to be done to another person. If it is about past unprosecuted } \\
\text { criminal offences I would maintain confidentiality' }\end{array}$ \\
\hline
\end{tabular}

Table 3: The social factors that influenced the decision-making process.

The debate around the severity of the crime was evident throughout the data collection. It was evident that the disclosure of information to the authorities occurred primarily in situations where therapists felt they had no other choice. Risk also played a substantial role in the decision-making. It was evident that reporting behavior was more common when there was a third-party risk. Similarly, potential harm to the client or others influenced the decision. On the other hand, past offences were perceived as low risk and thus reporting was not deemed as urgent.

Several core therapeutic factors emerged from the data (Table 4). Firstly, it was indicated that a major element affecting the decision- making process was the therapist's judgement of the client's reason for disclosure. Was this kind of disclosure important for the client, was it because the client was ready to come to terms with the reality of the situation or did it illustrate the strength of the client-therapist relationship. Exploring the reason for the disclosure and beginning the journey of coming to a decision of what needs to be said and what doesn't' seemed to be a common thread in reaching an ultimate reporting decision.

\begin{tabular}{|l|l|}
\hline \multicolumn{1}{|c|}{ Sub-Theme } & \multicolumn{1}{|c|}{ Quotes } \\
\hline The Purpose of the Disclosure & $\begin{array}{l}\text { 'And I suppose I have learnt that when clients disclose stuff in counselling that often they are already on the journey of coming to } \\
\text { a decision of what needs to be said and what doesn't...' } \\
\text { 'As therapists, we have a legal and ethical obligation to report all criminal activities, clear contracting makes clients aware of the } \\
\text { limits of confidentiality' }\end{array}$ \\
\hline The Contract & $\begin{array}{l}\text { 'Well there is no therapeutic relationship if you are holding onto that ... you are colluding with somebody' } \\
\text { 'The relationship and the client versus the law of the land here in Northern Ireland' }\end{array}$ \\
\hline $\begin{array}{l}\text { The Support Network for } \\
\text { Therapists }\end{array}$ & 'The ethical framework states that any major ethical decision making you need to talk to somebody else' \\
\hline
\end{tabular}

Table 4: The therapeutic factors that influenced the decision-making process.

The importance of the contract also emerged as an essential factor to protect both the client and the therapist. There was enormous emphasis placed on establishing clarity from the onset of therapy so that, if a disclosure occurs, both the therapist and the client are very clear on what needs to happen. This issue of the therapeutic contract relates directly to the third therapeutic factor, namely the therapeutic relationship itself.

The therapeutic relationship is a fundamental aspect of effective therapy and this was transparent from the qualitative data. For example, Participant B felt that the decision-making process would put the relationship 'under considerable strain'. The need for a good support system for therapists during the decision-making process became very apparent. However, a query was raised about how prepared the support system would be in relation to complex scenarios such as the ones presented.

Finally, Table 5 sets out the personal factors that impacted on the decision-making process. Each therapist brought his or her own background, training, culture, personality and societal norms into the process. Personal, social and moral obligations added further dynamics to the already conflicting ethical and legal frameworks. Additionally, participants questioned their role as a therapist faced with such a decision in terms of their legal obligations. The participants recognized the need for additional education and training to assist in future decision-making processes. It was reiterated by therapists that when faced with such ethical and legal dilemmas the decision to report or not would not be made quickly or alone. 
Page 6 of 8

\begin{tabular}{|l|l|}
\hline Sub-Theme & Quotes \\
\hline Education and Training & $\begin{array}{l}\text { 'just like you have to do your child protection stuff if you're working with children or vulnerable adults if you're working ....Why not do a } \\
\text { legal thing?' }\end{array}$ \\
\hline $\begin{array}{l}\text { The } \\
\text { Responsibility }\end{array}$ & 'it's moral, ethical, professional... but it's what I can live with as well as' \\
\hline The Therapist's Role & $\begin{array}{l}\text { 'I'm not a policeman l'm not society it is not the counsellors' role to keep the streets safe or whatever... because my primary role is } \\
\text { working with somebody who has come to me in pain and because confidentiality is such a huge part of that work and that's where it is } \\
\text { all built from the relationship so breaking that is a monumental big thing so it has to be a monumental an absolute without any grey } \\
\text { areas...' }\end{array}$ \\
\hline
\end{tabular}

Table 5: The personal factors that influenced the decision-making process.

\section{Discussion}

'As therapists, I see our role as bearing to hear the unhearable, witness the savagery and hurt done by our client and still hold them in loving, respectful and empathic presence' (Participant 21).

Almost half of respondents in the present study did not feel aware of their legal duties. Moreover, $25 \%$ believed that practitioners did not have a legal duty to report unprosecuted criminal offences and only $56.4 \%$ have ever undertaken training relating to their legal obligations. Therefore, therapists are not only not informed of their legal duties, which are critical to carrying out their occupation lawfully and to the best standard for clients, they are also not seeking out training. These findings concur with international research [33,34]. Additional research found over $76 \%$ of respondents were misinformed about their state laws, yet felt confident in their knowledge of their duty to warn obligations in the event of risk to the client or a third party [24]. The findings align with international research and highlight the need for clarity and training around legal obligations in a therapeutic setting.

Overall, the study identified that respondents acknowledged that they had a legal duty to report, yet nonetheless demonstrated nonreporting behavior. Consistent with previous research, underreporting of disclosures in a therapeutic setting was found to be a significant issue $[33,35]$. Scenario one was the most reported circumstance as it presented an explicit and more immediate risk to a third party. Factors such as the severity of the crime [34] and an immediate risk to a third party [29] have been found to increase reporting behavior.

Paradoxically, the findings indicate that reporters who had undertaken training and perceived themselves to have legal knowledge had greater levels of discomfort with their decision to report. Strozier and colleagues suggests that the ethical responsibility to protect the client can leave therapists feeling very uncomfortable with their decision to report [36]. In contrast to our findings, Sikes and team suggested that experience and training positively influenced experiences of reporting decisions [35]. Therapists' comfort levels with their reporting decision could influence the way in which a practitioner decides to proceed. Thus, the discrepancy in the results merits further investigation to identify the factors associated with feeling comfortable or uncomfortable in relation to reporting behavior. Ethical decision-making is very much influenced by the practitioner's personal beliefs, attitudes and morals [11]. The desire to balance law, ethics, social and moral responsibility was the most commonly cited reason influencing the reporting decision [37]. Thus, an extensive support system is required so that therapists are not expected to carry to burden of ethical decision making alone.
Therapists in the current investigation reported fear and safety issues as the most common reason for not reporting. Equally, Pope and Tabachnick [38] implied fear of violence towards the client, the therapist or a third party was the most prevalent feeling in relation to reporting. Similarly, Walfish et al. [30] described the fear of reporting unprosecuted criminal offences as very realistic. However, there are additional fears that are specific to nations in a transition from civil conflict to peace such as Northern Ireland, South Africa and Chile [21]. It must also be noted that the problems of intimidation, inter group violence and social control by criminal groups and terrorist organizations are not unique to civil conflict or to Northern Ireland [22]. Gang cultures and criminality is evident internationally and this makes disclosures complex for both the therapist and the client. Based on these findings, it is recommended that an appropriate reporting procedure be set out to protect the safety of the therapist while enabling them to report the disclosure, in accordance with the law.

It is important to interpret the findings in terms of the limitations of the study. Responses had the potential to be biased as non-responses could be attributed to not wanting to get the answers wrong or lack of awareness of the legislation. Therapists also reported an emotional drain associated with the decision-making process for the eight scenarios and even highlighted significant countertransference. An additional limitation was that the scenarios were hypothetical rather than real cases. The scenarios were typical of lived experiences within the context of the Northern Ireland Troubles. Therefore, the findings might not be replicated in other communities or with other population living in a post conflict society. However, the findings do raise interesting questions that could inform future research in different communities. It must also be noted that the study was undertaken with a modest sample size. There is no descriptive data to indicate the number of counsellors or psychotherapists in Northern Ireland, therefore, it was impossible to illustrate the representativeness of the sample. The sensitive nature of the study and the very fact the questionnaires challenged therapists to think of these issues both professionally and personally could have resulted in therapists' reluctance to take part. The length of the questionnaire could also be considered a barrier to response rates.

The current study highlighted numerous areas that could merit further investigation. The impact of the Troubles is imprinted within communities and on culture throughout Northern Ireland. Additional research is needed to explore how the lived experience of the Troubles resonates in the work environment of health care professionals. Numerous factors emerged that influenced the decision-making process. Based on the findings, further examination is required to explore how therapists in other jurisdictions address ethical and legal 
challenges presented by the disclosure of unprosecuted criminal offences. It is important to identify the strengths and gaps in knowledge so that practitioners, educators and professional bodies can provide appropriate guidance and training in this area.

\section{Implications for practice}

Psychologists are expected to provide a high standard of professional practice that is both ethical and law abiding in order to protect the client and the practitioner. Based on the current findings, it is recommended that an appropriate reporting procedure and clear guidelines be set out to protect the safety of the therapist while enabling the discharge of responsibilities in accordance with the law. An additional implication for practice was the need for increased levels of training and education. It is recommended that professional organizations advocate for mandatory training for all therapists. The importance of appropriate contracting should be integrated into training at all levels for therapists and the use of explicated examples to explain confidentiality limitations to clients should be encouraged.

Finally, therapeutic networks of support should be availed of to support ethical decision-making and challenging legal issues that emerge in practice. Additionally, appropriate support networks need to be put in place to assist therapists in these ethical decisions. Supports such as anonymous helplines and local support services are necessary to assist practitioners with the appropriate action and alleviate some of the personal responsibility associated with such a decision.

\section{Conclusion}

The purpose of this paper was to explore the ethical and legal challenges of a client's disclosure of an unprosecuted criminal offence in a therapeutic setting. It is evident from the research that therapists are challenged when presented with such a disclosure. It is important that clarity is sought, mandatory training is provided, and appropriate support networks are used and put in place to assist therapists in ethical decisions.

\section{References}

1. Younggren JN, Harris EA (2008) Can you keep a secret? Confidentiality in psychotherapy. J Clin Psychol 64: 589-600.

2. Graham-Bermann SA, Kulkarni MR, Kanukollu SN (2011) Is disclosure therapeutic for children following exposure to traumatic violence? J Interpers Violence 26: 1056-1076.

3. Jenkins P (2008) It's the law - isn't it? Ther Today 19: 30-33.

4. Cooper M (2004) Towards a relationally-orientated approach to therapy: empirical support and analysis. Br J Guid Counc 32: 451-460.

5. Donner MB, VandeCreek L, Gonsiorek JC, Fisher CB (2008) Balancing confidentiality: Protecting privacy and protecting the public. Prof Psychol Res Pract 39: 369-376.

6. General Medical Council. Confidentiality Guidance.

7. Michalawski S (2003) Medical Confidentiality and Crime. Farnham, Ashgate Publishing, England.

8. Department of Health and Social Northern Ireland (1998) Living with the trauma of the troubles.

9. Jenkins P (2010) Children at risk: a confidential space? Ther Today 21: 22-26.

10. Bond T, Brewer W, Mitchels B (2009) Breaches in Confidentiality: BACP information sheet G2.

11. Bunting L, Lazenbatt A, Wallace I (2009) Information sharing and reporting systems in the UK and Ireland: Professional barriers to reporting child maltreatment concerns. Child Abus Rev 19: 187-202.
12. Feenan D (2002) Legal Issues in Acquiring Information about Illegal Behaviour Through Criminological Research. Br J Criminol 42: 762-781.

13. Myers E, Hewstone M, Cairns E (2009) Impact of Conflict on Mental Health in Northern Ireland: The Mediating Role of Intergroup Forgiveness and Collective Guilt. Polit Psychol 30: 269-290.

14. Hayes BC, McAllister I (2001) Sowing Dragon's Teeth: Public Support for Political Violence and Paramilitarism in Northern Ireland. Polit Stud 49: 901-922.

15. Dawson G (2007) Making peace with the past: Memory, trauma and the Irish Troubles. Manchester: Manchester University Press, UK.

16. Bew P, Gillespie G (1999) Northern Ireland: A chronology of the troubles. Dublin, Gill and Macmillan, Ireland.

17. Cairns E, Darby J (1998) The conflict in Northern Ireland: Causes, consequences, and controls. Am Psychol 53: 754-760.

18. McGrellis S (2005) Pure and bitter spaces: gender, identity and territory in Northern Irish youth transitions. Gend Educ 17: 515-529.

19. Jameison R, Shirlow P, Grounds A (2010) Ageing and Social Exclusion Among Former Politically Motivated Prisoners in Northern Ireland.

20. Kapur R, Campbell J (2002) The troubled mind of Northern Ireland: Social care object relations theory and political conflict. J Soc Work Pract 16: 67-76.

21. Mac Ginty R, Muldoon OT, Ferguson N (2007) No War, No Peace: Northern Ireland after the Agreement. Polit Psychol 28: 1-11.

22. Edwards A, Levi M (2008) Researching the organization of serious crimes. Criminol Crim Justice 8: 363-388.

23. Donnan H, Simpson K (2007) Silence and Violence among Northern Ireland Border Protestants. Ethnos 72: 5-28.

24. Pabian YL, Welfel E, Beebe RS (2009) Psychologists' knowledge of their states' laws pertaining to Tarasoff-type situations. Prof Psychol Res Pract 40: 8-14.

25. Chenneville T (2000) HIV, confidentiality, and duty to protect: A decision-making model. Prof Psychol Res Pract 31: 661-670.

26. Huprich S, Fuller K, Schneider R (2003) Divergent Ethical Perspectives on the Duty-to-Warn Principle With HIV Patients. Ethics Behav 13: 263-278.

27. Bryant JK, Baldwin PA (2009) School counsellors' perceptions of mandatory reporter training and mandatory reporting experiences. Child Abus Rev 19: 172-186.

28. Webster SW, O'Toole R, O’Toole AW, Lucal B (2005) Overreporting and underreporting of child abuse: Teachers' use of professional discretion. Child Abuse Negl 29: 1281-1296.

29. Kampf A, Mcsherry B, Thomas S, Abrahams H (2008) Psychologists perceptions of legal and ethical requirements for breaching confidentiality. Aust Psychol 43: 194-204.

30. Walfish S, Barnett JE, Marlyere K, Zielke R (2010) "Doc, There's Something I Have To Tell You": Patient Disclosure to Their Psychotherapist of Unprosecuted Murder and Other Violence. Ethics Behav 20: 311-323.

31. Brown AP (2006) "In my agency it"s very clear - but I can't tell you what it is': Work settings and ethical challenges. Couns Psychother Res 6: 100-107.

32. Ferry F, Bolton D, Bunting B, Devine B, McCann S, et al. (2008) Trauma, Health and Conflict in Northern Ireland.

33. Bryant J, Milsom A (2005) Child Abuse Reporting by School Counselors. Prof Sch Couns 9: 63-71.

34. Renninger SM, Veach PM, Bagdade P (2002) Psychologists' knowledge, opinions, and decision-making processes regarding child abuse and neglect reporting laws. Prof Psychol Res Pract 33: 19-23.

35. Sikes A, Remley TPJ, Hays DG (2010) Experiences of School Counselors during and after Making Suspected Child Abuse Reports. J Sch Couns 8: 1 .

36. Strozier M, Brown R, Fennell M, Hardee J, Vogel R (2005) Experiences of mandated reporting among family therapists. Contemp Fam Ther 27: 177-191. 
Citation: Lynn JD, Daly C, Rhys C (2016) The Elephant in the Room: Dealing with an Unprosecuted Criminal Disclosure in a Therapeutic Setting. J Foren Psy 1: 114. doi:10.4172/2475-319X.1000114

Page 8 of 8

37. Knapp S, Gottlieb M, Berman J, Handelsman MM (2007) When laws and ethics collide: What should psychologists do? Prof Psychol Res Pract 38: 54-59.

38. Pope KS, Tabachnick BG (1993) Therapists' anger, hate, fear, and sexual feelings: National survey of therapist responses, client characteristics, critical events, formal complaints, and training. Prof Psychol Res Pract 24: $142-152$. 